\title{
MEDIA KARTU DERIVATIF DALAM PEMBELAJARAN TURUNAN
}

\author{
I Wayan Laba \\ SMK Negeri 1 Kubu, Jalan Raya Kubu, Karangasem, iwayanlaba106@gmail.com
}

\begin{abstract}
Abstrak. Penelitian ini bertujuan memaparkan suatu alternatif strategi dalam pembelajaran matematika materi turunan berbasis media kartu derivatif, yang dilandasi oleh pandangan konstruktivisme. Pembelajaran matematika dengan prinsip-prinsip konstruktivisme ini akan dapat membantu siswa untuk mengkonstruksi pengetahuan/pemahamannya sendiri sehingga pengetahuan konsep yang dimiliki menjadi lebih resisten. Sedangkan media kartu derivatif merupakan alternatif media untuk membantu siswa memahami konsep-konsep differensial/turunan melalui permainan sehingga pembelajaran menjadi bermakna.
\end{abstract}

Kata Kunci : media kartu derivatif, pembelajaran turunan, konstruktivisme

\section{Derivative Card Media in The Teaching and Learning of Derivative Topic}

\begin{abstract}
This study describes an alternative strategy in mathematics teaching and learning on derivative topic using derivative card-based media, which refers to constructivism view. Mathematics teaching and learning using constructivism principles will enable the students to construct their own knowledge/understanding so that their conceptual knowledge becomes more resistant. Meanwhile, derivative card media is an alternative media to help students understand the concepts of differential/derivative through games so that it emerges a meaningful learning.
\end{abstract}

Keywords: derivative card media, derivative teaching and learning, constructivism

\section{Pendahuluan}

Mathematics is the Queen Of The Science merupakan pernyataan matematika adalah ratunya berbagai bidang ilmu. Matematika merupakan ilmu universal yang mendasari perkembangan teknologi modern, mempunyai peran penting dalam berbagai disiplin dan mengembangkan daya pikir manusia (Depdiknas, 2006: 105). Jadi matematika merupakan ilmu dasar dalam perkembangan IPTEK yang tidak terpisahkan dari kehidupan manusia. Belajar matematika berkaitan dengan konsep-konsep abstrak yang berkenaan dengan ide-ide, struktur-struktur dan hubungan-hubungan yang diatur secara logis yang akan membawa terjadinya proses pembelajaran matematika itu. Keberhasilan atau kegagalan dalam belajar matematika sangat tergantung pada bagaimana proses pembelajaran itu dilaksanakan. Proses pembelajaran merupakan komponen yang perlu mendapat perhatian sebab dalam proses pembelajaran ini kognitif dan attitude siswa akan terbentuk yang mempengaruhi hasil belajar siswa.

Kenyataan menunjukkan bahwa banyak siswa yang mengeluh dan beranggapan bahwa matematika itu sulit dan merupakan momok, akibatnya mereka tidak menyenangi pelajaran 
matematika yang bermuara pada hasil belajar matematika yang rendah baik dari aspek kognitif maupun aspek afektif. Ditinjau dari aspek afektif bahwa matematika sangat sulit untuk dipahami yang berpengaruh pada sikap siswa pada matematika. Siswa beranggapan bahwa matematika merupakan pelajaran yang menyulitkan dan kurang menarik, sehingga dengan sendirinya dalam mengikuti pelajaran matematika siswa akan selalu ketakutan akibatnya apapun yang dipelajari akan tidak diserap dengan baik yang akhirnya mengakibatkan kompetensi matematika sulit tercapai. Rendahnya hasil belajar matematika khususnya yang menyangkut aspek kognitif yakni hasil belajar matematika tidak terlepas dari peran guru dan siswa dalam proses pembelajaran. Selama ini kebanyakan guru mengawali kegiatan pembelajaran dengan memberikan definisi-definisi formal, teoremateorema dan selanjutnya memberikan contoh-contoh soal. Jadi guru belum memperhatikan pengetahuan awal siswa dan juga siswa tidak diberikan kesempatan untuk mengkonstruksi konsep-konsep sendiri sehingga yang mendominasi kegiatan pembelajaran adalah guru. Bagi para siswa belajar matematika tampaknya hanya untuk menghadapi ujian dan ulangan, di mana materi matematika dirasakan sebagai beban yang harus diingat, dihafalkan dan dipahami. Jadi siswa belum biasa belajar mandiri dan motivasi belajar siswa masih rendah.

Rendahnya hasil belajar matematika siswa juga disebabkan oleh kurangnya pengetahuan konseptual siswa. Selama ini pengetahuan siswa cenderung bersifat prosedural. Siswa hanya dituntut terampil menggunakan rumus-rumus agar mampu mengerjakan matematika secara praktis. Guru sudah merasa puas setelah melihat siswanya mampu mengerjakan matematika sesuai dengan prosedurnya saja tanpa memperhatikan konsep yang terkandung di dalamnya. Konsep-konsep matematika hanya dihafalkan oleh siswa tanpa melalui pemahaman terlebih dahulu. Pengetahuan prosedural bukan berarti tidak diperlukan namun pengetahuan prosedural dan konseptual adalah saling melengkapi. Dalam hal ini siswa diharapkan mempunyai prosedural, konseptual secara berimbang agar siswa betul-betul mempunyai kemampuan yang optimal dalam matematika. Berdasarkan uraian di atas maka implementasi konstruktivisme merupakan salah satu alternatif yang dapat digunakan dalam pembelajaran.

Panen (2001) menyatakan bahwa konstruktivisme adalah pendekatan belajar dengan menekankan siswa untuk mendapatkan pemahaman baru dari pengalaman-pengalaman berdasarkan pengetahuan yang diperoleh sebelumnya. Hendra Syarifuddin (2016) menyatakan bahwa konstruktivisme adalah suatu teori tentang belajar yang berdasarkan pada pandangan bahwa pelajar adalah pencari ilmu yang aktif yang didorong oleh rasa keingintahuan mereka. Konsep utama konstruktivisme bahwa belajar merupakan suatu proses aktif penciptaan pengetahuan oleh siswa, dimana siswa mengkonstruksi pengetahuannya untuk membangun pemahaman. Berdasarkan pendapat tersebut, konstruktivisme merupakan pendekatan belajar dimana siswa mengkonstruksi pengetahuan dalam pikiran mereka melalui pembelajaran yang dilakukan sendiri dari pengalaman berdasarkan pengetahuan sebelumnya. Pendekatan belajar konstruktivisme akan mampu mengasah potensi kreativitas siswa. Siswa dibiasakan membangun sendiri pengetahuannya melalui keterlibatan aktif dalam proses belajar mengajar. Siswa menjadi pusat kegiatan.

Memahami konsep matematika yang bersifat abstrak dibutuhkan benda-benda konkrit ataupun manipulatif. Menurut Subanji (2013), dalam pembelajaran matematika sangat penting untuk menekankan media (peraga) untuk mengembangkan pemahaman siswa. 
Dengan melakukan sendiri (learning by doing), media dapat membuat siswa aktif dalam proses pembelajaran. Hal serupa diungkapkan Asyhar (2012) bahwa, media memiliki peran dan fungsi strategi yang secara langsung maupun tak langsung dapat mempengaruhi motivasi, minat dan atensi siswa dalam belajar serta mampu memvisualisasikan materi abstrak yang diajarkan sehingga memudahkan siswa. Menurut Suwarni (2014) menggunakan media adalah salah satu cara yang baik bagi guru untuk menyajikan pembelajaran yang menarik di dalam kelas. Berdasarkan uraian diatas, media merupakan alat bantu dalam pembelajaran sehingga siswa dapat memahami konsep melalui suasana pembelajaran yang lebih menyenangkan.

Kurang tersedianya media pembelajaran untuk materi Turunan menyebabkan materi ini kurang diminati oleh siswa. Diperlukan suatu media pembelajaran yang mampu meningkatkan aktivitas dan minat belajar siswa dibandingkan pembelajaran konvensional. Salah satu alternatif media yang digunakan adalah media kartu derivatif. Media kartu derivatif mengarahkan siswa untuk belajar secara bermakna, dengan belajar sambil bermain. Melalui media kartu, konsep materi turunan akan dipahami lebih terstruktur dalam pemikiran siswa, karena siswa tidak hanya menghafal rumus saja namun dapat lebih memaknai konsep materi Turunan. Sehubungan dengan hal tersebut, maka dalam penelitian ini akan dibahas suatu alternatif strategi pembelajaran dalam meningkatkan aktivitas, pengetahuan konseptual dan hasil belajar siswa, dalam pembelajaran matematika materi turunan berbasis media kartu derivatif berlandaskan pandangan konstruktivisme.

Penelitian ini bertujuan memaparkan suatu alternatif strategi dalam pembelajaran matematika materi turunan berbasis media kartu derivatif yang dilandasi oleh pandangan konstruktivisme. Karakteristik konstruktivisme yakni: siswa berinteraksi dengan obyek dan peristiwa, siswa membangun konseptualisasi sendiri, terjadinya kemandirian dan inisiatif belajar siswa, terjadinya belajar kooperatif, memberikan kesempatan kepada siswa membangun pengetahuan dan pemahaman baru berrdasarkan pengalaman nyata. Pembelajaran matematika dengan prinsip-prinsip konstruktivisme ini akan dapat membantu siswa untuk mengkonstruksi pengetahuan/pemahamannya sendiri sehingga pengetahuan konsep yang dimiliki menjadi lebih resisten. Sedangkan media kartu derivatif merupakan alternatif media untuk membantu siswa memahami konsep-konsep differensial/turunan melalui permainan sehingga pembelajaran menjadi lebih menyenangkan dan tidak membosankan.

\section{Konstruktivisme dalam Pembelajaran}

Belajar matematika menurut pandangan konstruktivisme (Herman Hudojo, 2002 : 21) adalah memantau siswa untuk membangun konsep-konsep atau prinsip-prinsip matematika dengan kemampuannya sendiri melalui proses internalisasi sehingga konsep atau prinsip itu dibangun kembali, transformasi informasi yang diperoleh menjadi konsep atau prinsip baru. Transformasi mudah terjadi bila terjadi pemahaman dengan terbentuknya skemata dalam benak siswa. Dengan demikian pembelajaran matematika adalah membangun pemahaman. Proses membangun pemahaman ini lebih penting daripada hasil belajar sebab pemahaman akan mengakibatkan materi yang dipelajari akan lebih bermakna. Makna belajar tidak mengutamakan perolehan pengetahuan yang banyak, tetapi yang lebih utama adalah memberikan interpretasi melalui skemata yang dimiliki siswa. 
Prinsip dasar konstruktivisme menurut Fosnot adalah sebagai berikut: 1) pengetahuan terdiri dari konstruksi-konstruksi masa silam (past contruction), 2) pengkonstruksian terjadi melalui akomodasi dan asimilasi, 3) mengacu pada belajar merupakan suatu proses organik penemuan, lebih dari pada suatu proses mekanik mengakumulasi, konstruktivisme mengambil posisi bahwa siswa harus mendapat pengalaman berhipotesis dan memprediksi, memanipulasi obyek, mengajukan pertanyaan, mencari jawaban berimajinasi, meneliti dan menemukan, dalam upaya mengembangkan pengalaman dan pengetahuan baru, dan 4) mengacu pada mekanisme yang memungkinkan berlangsungnya perkembangan kognitif, belajar bermakna terjadi melalui refleksi dan pemecahan konflik-konflik (Aryantini, 2003).

Berdasarkan hal tersebut, maka dalam mengkonstruksi pengalaman kita tentang dunia obyek dengan memandang melalui suatu kerangka logis yang mentransformasi, mengorganisasi dan menginterpretasi pengalaman kita, selanjutnya menggunakan asimilasi sebagai suatu kerangka logis dalam rangka menginterpretasi informasi baru dan akomodasi dalam rangka memecahkan kontradiksi-kontradiksi sebagai bagian dari proses regulasi diri yang lebih luas. Dari perspektif ini, jelas diperlukan proses pembelajaran yang berpusat pada siswa, dengan model instruksional yang aktif. Siswa harus membangun pengetahuan secara aktif dan guru berperan sebagai mediator yang kreatif.

Di dalam pembelajaran, perolehan informasi tidak berasal dari satu arah dari sumber ke penerima informasi, tapi pemberian makna oleh siswa kepada pengalamannya melalui proses asimilasi dan akomodasi sehingga skemata (jaringan konsep menjadi stabil) ini berarti proses pembelajaran merupakan pengolahan, pemrosesan ide agar terjadi refleksi dan abstraksi dalam benak siswa sehingga dalam interaksi belajar mengajar matematika tidak semata-mata pengalaman siswa terhadap lingkungan dan fasilitasnya. Menurut Skemp (Herman Hudojo, 2002: 3) pengetahuan harus dibangun oleh siswa sendiri berasarkan pengalaman yang telah dimiliki sebelumnya. Menurut Jones dan Thornton (Herman Hudojo, 2002: 2), agar siswa dapat membangun pemahamannya terhadap konsep atau prinsip matematika perlu adanya intervensi bantuan orang lain (misalnya guru atau teman yang lebih mampu) sehingga perlu adanya saling bernegosiasi secara mental antara siswa dengan guru, antara siswa dengan siswa. Dengan demikian pemahaman siswa terbangun diperlukan kolaborasi antara guru dengan siswa dan siswa dengan siswa. Dari kolaborasi ini terjadi internalisasi dalam belajar. Paradigma konstruktivisme yang mendasari desain pembelajaran yang dikemukakan oleh Wilson (Herman Hudojo, 2002: 2) adalah sebagai berikut: 1) mental sebagai representasi internal dari realitas luar, 2) pengetahuan diposisikan dalam mental individu, 3) makna secara internal dikonstruk, 4) refleksi dan abstraksi individu adalah utama, dan 5) pembelajaran berarti konstruksi yang dinegosiasikan dari makna.

Dari uraian di atas pendekatan konstruktivis di satu pihak menekankan berfikir dan makna kreasi individual sebagaimana Teori Piaget, dipihak lain perlunya negosiasi makna dalam kolaborasi sebagaimana teori Brunner dan Vygostsky, maka kerangka kerja konstruktivisme menjadi lebih longgar seperti berikut: 1) pengetahuan dikonstruk dari pemahaman, 2) belajar menghasilkan interpretasi personal dari pengetahuan, 3) belajar adalah suatu proses aktif yang dikembangkan atas dasar pengalaman, 3) belajar adalah kolaboratif dengan makna yang dinegosiasikan dari berbagai perspektif, 4) belajar seharusnya terjadi dalam situasi realistik, dan 5) tes diintegrasikan ke dalam proses belajar, tidak merupakan kegiatan yang 
terpisah. Dengan demikian pembelajaran dengan pendekatan konstruktivisme ini memerlukan penilaian yang lebih terpadu daripada penilaian pada pembelajaran hasil tes atau ujian saja. Karakteristik teori konstruktivisme dalam pembelajaran (Efendi, 2001) dapat dilihat pada tabel berikut.

Tabel 1. Karakteristik Teori Konstruktivisme dalam Pembelajaran

\begin{tabular}{|l|l|}
\hline \multicolumn{1}{|c|}{ Aspek } & \multicolumn{1}{c|}{ Karakteristik } \\
\hline Individualisasi & Tugas-tugas disesuaikan dengan perkembangan kognitif siswa. \\
\hline Motivasi & Menekankan motivasi instrinsik. \\
\hline Derajat sistemisasi & $\begin{array}{l}\text { Pembelajaran secara sistematik, tetapi lingkungan kelas memberi } \\
\text { peluang eksplorasi pada penemuan. }\end{array}$ \\
\hline Metodologi & Bahan ajar dan metodologi diarahkan pada keterampilan kognitif. \\
\hline Pemahaman & Menekankan pada pemahaman dan kebermaknaan. \\
\hline Tujuan pendidikan & Menerapkan kecerdasan dalam keputusan dan dapat berinovasi. \\
\hline Tujuan pembelajaran & $\begin{array}{l}\text { Menekankan perkembangan total: "sensory motor" kemampuan } \\
\text { kognitif dan bahasa. }\end{array}$ \\
\hline Pengelolaan kelas & Pembelajaran terpusat pada siswa. \\
\hline
\end{tabular}

Menurut "Principle Of Construktivist Learning" (Efendi, 2001: 7) ada enam fase daur belajar konstruktivisme yaitu sebagai berikut: 1) fase identifikasi kompetensi dasar dari kurikulum dan guru, misalnya: pokok bahasan diferensial/turunan siswa dapat menggunakan konsepkonsep turunan dalam memecahkan masalah matematika dalam kehidupan sehari-hari, 2) fase mengakses pengetahuan terdahulu yang dimiliki oleh siswa, tujuannya untuk mengetahui apa saja yang sudah diketahui para siswa, misalnya: pokok bahasan turunan kita menanyakan "Apa itu Fungsi?, Apa itu Variable? Apa itu Konstanta?", 3) fase Eksplorasi tujuannya untuk mengecek apakah pengetahuan yang dimiliki oleh siswa benar, separuh benar atau salah. Ini dilakukan dengan menyuruh siswa menjelaskan pengetahuannya di depan kelas/dibangkunya, 4) fase menjelaskan, dalam fase ini guru memberikan kesempatan agar para siswa menghubungkan pemahaman baru dengan konsep terdahulu. Ini dilakukan dengan memberikan siswa kesempatan untuk mendiskusikan dengan teman sebangkunya, 5) fase elaborasi, dalam fase ini guru memberikan kesempatan agar para siswa menerapkan pemahaman baru pada konteks yang berbeda. Ini dilakukan dengan memberikan permasalahan baru mengenai konteks yang dibahas, dan 6) fase evaluasi, adalah fase untuk menilai perubahan-perubahan dalam situasi baru. Pada fase ini diadakan evaluasi untuk menilai pemahaman siswa dengan membandingkan kompetensi dasar pada fase I. Berdasarkan uraian diatas, maka konstruktivisme yang akan digunakan adalah fase: identifikasi kompetensi dasar, apersepsi, eksplorasi, menjelaskan, elaborasi, dan evaluasi.

\section{Pengetahuan Konseptual dalam Pembelajaran Matematika}

Pengetahuan konseptual merupakan suatu jalinan jaringan yang mengikat serpihan-serpihan informasi menjadi suatu bagian yang relatif lengkap dan utuh (Hamdani, 2015). Pengetahuan konseptual dalam matematika merupakan pengetahuan dasar yang menghubungkan antara potongan-potongan infomasi yang berupa fakta, skill, konsep atau prinsip (Hiebert \& Wearne, 1986). Sesuai dengan pendapat tersebut dapat dijelaskan bahwa pengetahuan konseptual dari matematika adalah pengetahuan yang terdiri dari ide dan konsep yang saling 
berhubungan dan berintegrasi atau dihubungkan ke ide/konsep matematika yang lain. Pengetahuan konseptual adalah suatu pengetahuan yang tidak merupakan informasi yang tidak terisolasi namun sebaliknya pengetahuan konseptual itu merupakan hubungan dari informasi lain misalnya dalam turunan terdapat pengetahuan tentang konsep bilangan berpangkat tentunya dibangun pengetahuan konseptual penjumlahan, pengurangan, perkalian dan pembagian bilangan berpangkat. Dalam memecahkan suatu persoalan matematika tidak hanya tahu prosedur penyelesaian soal saja tetapi siswa harus tahu alasan mengapa prosedur seperti itu digunakan untuk menyelesaikan persoalan itu. Untuk dapat memberikan alasan maka siswa harus mampu menentukan hubungan antara persoalan tersebut dengan konsepkonsep matematika.

Pengetahuan konseptual dalam pembelajaran matematika dapat digambarkan melalui pemahaman siswa terhadap konsep-konsep matematika dan kebermaknaan belajar siswa. Menurut Suarjana beberapa aktivitas yang perlu dilakukan untuk mengetahui pemahaman siswa yaitu: 1) membandingkan atau menetapkan antara dua lebih fenomena, 2) menetapkan perbedaan antara dua atau lebih fenomena, 3) memilih perumusan konsep yang benar, 4) menjelaskan arti konsep itu melalui perumusan yang diciptakan siswa sendiri, dan 5) melakukan suatu kegiatan yang mencerminkan konsep itu. (Ike Laksmiyeni, 2004). Siswa dikatakan belajar bermakna jika siswa mampu mengaitkan materi atau konsep yang sudah ada dalam struktur kognitifnya dengan konsep yang baru dipelajari. Siswa akan belajar secara bermakna jika guru mengajar secara bermakna. Dalam belajar bermakna guru harus mampu memilih materi yang akan diajarkan pada siswa yang disesuaikan dengan struktur kognitif dan pengetahuan yang sudah dimiliki sebelumnya. Selain itu, belajar bermakna dapat dilaksanakan dengan membawa situasi kehidupan nyata siswa ke dalam kelas dan dijadikan pangkal pembentukan matematika.

Model pembelajaran dengan prinsip-prinsip konstruktivisme berbasis media kartu derivatif merupakan salah satu bagian dari instrumental input. Dalam pembelajaran dengan menggunakan prinsip-prinsip konstruktivisme siswa diberikan kesempatan mengkonstruksi pengetahuan yang telah dimiliki dengan kemampuannya sendiri melalui proses internalisasi sehingga konsep atau prinsip itu terbangun kembali dan transformasi informasi yang diperoleh menjadi konsep atau prinsip baru. Transformasi terjadi seiring terjadinya pemahaman yang membentuk skemata dalam benak siswa. Proses membangun pemahaman lebih penting daripada hasil belajar sebab pemahaman akan mengakibatkan materi yang dipelajari menjadi bermakna.

Dengan diberikannya kebebasan pada siswa untuk menemukan konsep-konsep matematika sendiri, maka kecenderungan siswa untuk menghafal konsep-konsep tersebut akan dapat dengan mudah dikuasai oleh siswa tentunya disertai oleh pemahaman yang kuat. Sedangkan dengan dilibatkannya masalah-masalah kehidupan nyata ke dalam pembelajaran maka siswa akan mampu mengaitkan apa yang sudah ada dalam benaknya dengan konsep yang baru dipelajarinya. Sedangkan media kartu derivatif merupakan alternatif media yang dapat membantu siswa memahami konsep-konsep differensial/turunan melalui permainan sehingga pembelajaran menjadi lebih menyenangkan dan tidak membosankan. Media kartu derivatif merupakan stimulus yang dapat direspon siswa dengan tumbuhnya motivasi untuk belajar matematika dan konsep-konsep yang dibelajarkan akan melekatkan pada ingatan anak secara 
permanen, karena siswa dapat belajar sambil bermain. Dengan demikian siswa dikatakan belajar secara bermakna. Jika siswa sudah belajar secara bermakna dan siswa sudah memahami konsep-konsep matematika yang dipelajari maka siswa dapat dikatakan sudah memiliki pengetahuan konseptual. Siswa tidak hanya tahu algoritma penyelesaian soal tetapi juga mampu menjelaskan mengapa seperti itu.

\section{Media Kartu Derivatif dalam Pembelajaran Turunan}

Dalam pembelajaran sangat diperlukan media sebagai alat bantu sehingga siswa dapat memahami konsep melalui suasana pembelajaran yang lebih menyenangkan. Alat bantu pembelajaran menurut Mendra (2003) digolongkan menjadi tiga fungsi yaitu sebagai alat: 1) peraga, 2) praktek dan 3) permainan. Sehubungan fungsi tersebut, penulis akan memaparkan suatu alternatif media yang dapat difungsikan sebagai alat permainan dalam menanamkan konsep differensial/turunan. Permainan ini berguna bagi siswa untuk menguatkan keterampilan dan mengurangi kejenuhan siswa dalam belajar matematika, di mana dalam mempelajari konsep diferensial memerlukan analisis dan daya nalar yang tinggi. Untuk menanamkan konsep differensial ini penulis merancang suatu media yang dalam tulisan ini disebut kartu derivatif.

Rancangan kartu derivatif dibuat dengan menggunakan kertas manila. Bentuk, ukuran dan jumlah kartu dapat disesuaikan dengan konsep yang ingin disampaikan, kemampuan dan seni guru sendiri. Dalam penelitian ini, satu set kartu terdapat 24 jenis kartu yang berbeda di mana enam jenis kartu memuat enam buah fungsi yang berbeda dan kartu yang lainnya merupakan turunan (dari turunan pertama sampai turunan ketiga) dari keenam fungsi tersebut. Sehingga kartu tersebut dapat dimainkan oleh 2 orang, 3 orang, 4 orang atau 6 orang. Dalam permainan digunakan 2 set kartu yang sama sehingga jumlahnya 48 kartu dengan masing-masing dua buah kartu yang sama. Kartu yang dibuat dibedakan menjadi 3, menurut pangkat atau derajat dari fungsinya, yaitu: 1) pangkat bulat positif (kartu berwarna hijau), 2) pangkat bulat negatif (kartu berwarna kuning), 3) pangkat rasional (kartu berwarna merah).

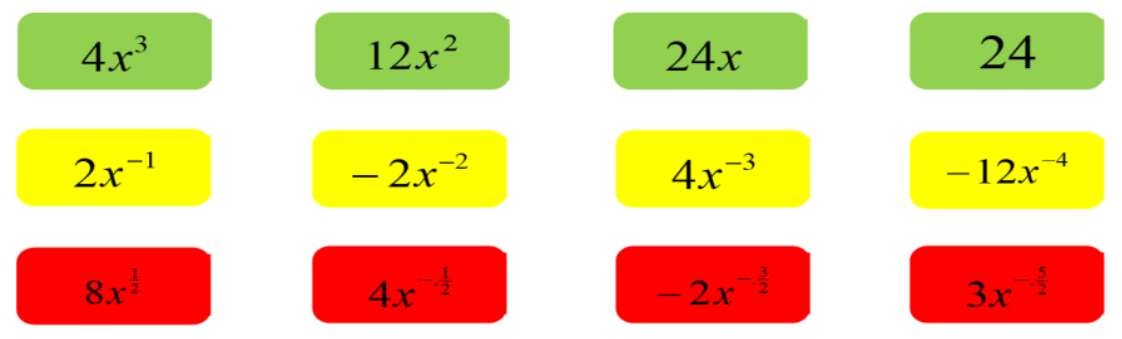

Gambar 1. Contoh Kartu Derivatif

Permainan dapat dilaksanakan di dalam kelas atau di luar kelas dan disesuaikan dengan waktu yang tersedia. Jenis-jenis permainan dan aturannya seperti uraian berikut.

\subsection{Permainan ala Domino}

Permainan ini dapat dimainkan oleh dua, tiga, empat atau enam pemain, di mana aturan permainannya merupakan manipulasi dari permainan domino. Dalam permainan ini semua 
kartu dibagi rata sesuai dengan jumlah pemain. Permainan dalam satu babak terdiri dari beberapa game sesuai dengan waktu yang ditentukan. Aturan permainan:

1) Pemain pertama (sesuai undian) memasang sebuah kartunya, misal: $12 x^{2}$.

2) Pemain kedua (putaran positif) melanjutkan dengan memasang fungsi turunannya, yaitu $24 x$ di sebelah kanannya atau bisa juga fungsi asalnya yaitu $4 x^{3}$ di sebelah kiri.

3) Jika tidak ada lagi kartu yang dapat dipasang, maka telah terjadi game I pada babak I.

4) Permainan dilanjutkan dengan game II dan pemain I pada game II adalah pemain yang memasang kartu terakhir pada game I. Pemain I berhak memasang sembarang kartunya.

5) Pemain berikutnya boleh memasang fungsi turunan atau fungsi asal seperti pada game I sampai terjadi pada game II.

6) Babak pertama akan selesai jika salah satu pemain sudah kehabisan kartu (sekaligus sebagai pemenang babak tersebut).

7) Permainan dilanjutkan dengan permainan babak selanjutnya dengan aturan yang sama.

\subsection{Permainan Minum}

Permainan ini merupakan modifikasi dari permainan kartu biasa (kartu remi). Dalam permainan ini kartu yang dibagi hanya sebagian saja (sesuai kesepakatan), yaitu masingmasing pemain memegang 4 buah kartu dan sisanya ditaruh di tengah bidang permainan (posisi tulisan tidak tampak). Aturan Permainan :

1) Pada babak I, pemain 1 (sesuai undian) memasang sebuah kartunya.

2) Pemain II (putaran positif) wajib mengeluarkan kartu yang merupakan fungsi turunan atau fungsi asal dari kartu pemain I. Jika pemain II tidak memilikinya, maka ia wajib mencari sebuah kartu dari sisa kartu yang ada secara berurutan sampai mendapatkan kartu yang sesuai (istilahnya minum). Sedangkan kartu yang telah diambil yang bukan dalam garis turunan menjadi miliknya.

3) Setelah setiap peserta memperoleh kartu yang sesuai, maka terjadi game I dan semua kartu yang telah dipakai (dianggap mati) dikeluarkan dari bidang permainan,

4) Permainan dilanjutkan pada game II. Pemain I pada game II adalah pemain yang mengeluarkan kartu dengan pangkat tertinggi pada game I, berhak memasang sembarang kartunya. Pemain selanjutnya melanjutkan seperti pada game I.

5) Demikian seterusnya sampai semua kartu sisa habis dipakai (babak I selesai). Sebagai pemenangnya adalah pemain yang memiliki kartu paling sedikit atau yang kartunya paling dulu habis. Permainan dilanjutkan pada babak II dan sebagai pemain I pada babak II adalah pemenang babak I.

\section{Kesimpulan dan Saran}

Berdasarkan kajian secara teoritis, dapat disimpulkan bahwa pembelajaran matematika dengan paham konstruktivisme berbasis media kartu derivatif merupakan salah satu alternatif pembelajaran yang dapat diterapkan dengan menghubungkan turunan beberapa fungsi sambil bermain sehingga konsep turunan tidak hanya menjadi hafalan dan pembelajaran menjadi lebih bermakna.

Saran yang disampaikan kepada pembaca agar dapat dikembangkan alternative pembelajaran dengan prinsip-prinsip konstruktivisme dalam materi lain. 


\section{Daftar Pustaka}

Aryantini. 2003. Efektivitas Strategi Pengubah Konsepsi dengan Siklus Belajar Hipotesis-Deduktif dalam Pembelajaran IPA (Fisika) di SMU Negeri 2 Singaraja. (tidak diterbitkan). Jurusan Pendidikan Fisika, Fakultas Pendidikan MIPA IKIP Negeri Singaraja.

Asyhar, R. 2012. Kreatif Mengembangkan Media Pembelajaran. Jakarta: Referensi.

Depdiknas. 2006. Peraturan Mendiknas RI Nomor 22 Tahun 2006 Tentang Standar Isi untuk Satuan Pendidikan Dasar dan Menengah. Jakarta.

Efendi. 2001, Media Komunikasi Kimia. Malang: FPMIPA Universitas Negeri Malang.

Herman Hudojo. 2002. Penilaian Belajar Matematika Konstruktivisme (proyek Due-Like Jurusan Pendidikan Matematika IKIP N Singaraja Tahun 2002. (Tidak diterbitkan).

Hamdani. 2015. Meningkatkan Pengetahuan Konseptual dan Pengetahuan Prosedural Mahasiswa Melalui Pendekatan Diskursus Matematik. Jurnal Pendidikan Matematika dan IPA, 6(1): 1325.

Hendra Syarifuddin. 2016. Peningkatan Efektifitas Perkuliahan Aljabar Linear Elementer Melalui Penggunaan Peta Konsep. Prosiding KONASPI VIII Tahun 2016. Universitas Negeri Jakarta.

Ike Laksmiyeni. 2004. Pengaruh Penerapan Pendekatan Realistik Terhadap Pengetahuan Prosedural Matematika Siswa Kelas II SLTP Negeri 1 Singaraja. Jurusan Pendidikan Matematika IKIP Negeri Singaraja Tahun 2002. (Tidak diterbitkan).

Mendra, Ketut. 2003. Penggunaan Kartu Derivatif untuk Meningkatkan Hasil Belajar Matematika Kelas II/2 SMU Negeri Singaraja pada Pokok bahasan Differensial. Jurnal Ilmiah IKA: IKIP Negeri Singaraja.

Panen, Paula, Dina Mustafa, \& Mestika Sekar Winahyu. 2001. Konstruktivisme dalam Pembelajaran. Jakarta: Dikti Depdiknas.

Subanji. 2013. Pembelajaran Matematika Kreatif dan Inovatif. Malang: Universitas Negeri Malang.

Suwarni. 2014. Meningkatkan Hasil Belajar Siswa Pokok Bahasan Penjumlahan dan Pengurangan Bilangan Bulat dengan Media Manik-Manik pada Siswa Kelas IV SDN Tanggul Wetan 02 Tahun Pelajaran 2011/2012 Kecamatan Tanggul-Jember. Jurnal Pancaran. Vol.3, No.3, Agustus 2014, 177-186. 